\title{
Correction to: Improving the usability and comprehensiveness of microbial databases
}

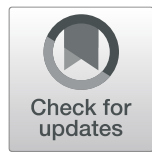

Caitlin Loeffler ${ }^{1,2^{*+}}$, Aaron Karlsberg ${ }^{2 \dagger}$, Lana S. Martin ${ }^{2}$, Eleazar Eskin ${ }^{1,3,4}$, David Koslicki ${ }^{5,6,7}$ and Serghei Mangul ${ }^{2^{*}}$

\section{Correction to: BMC Biol (2020) 18:37 \\ https://doi.org/10.1186/s12915-020-0756-z}

Following publication of the original article [1], the authors identified an error in the affiliations of Serghei Mangul: the second affiliation (number 8 ) needs to be removed. The corrected affiliation information for Serghei Mangul can be found in the affiliation list of this Correction article.

\begin{abstract}
Author details
'Department of Computer Science, University of California Los Angeles, 404 Westwood Plaza, Los Angeles, CA 90095, USA. ²Department of Clinical Pharmacy, University of Southern California School of Pharmacy, 1985 Zonal Ave, Los Angeles, CA 90089, USA. 'Department of Human Genetics, David Geffen School of Medicine at UCLA, 695 Charles E. Young Drive South, Box 708822, Los Angeles, CA 90095, USA. ${ }^{4}$ Department of Computational Medicine, David Geffen School of Medicine at UCLA, 73-235 CHS, Los Angeles, CA 90095, USA. ${ }^{5}$ School of Computer Science and Engineering, The Pennsylvania State University, 207 Electrical Engineering West, University Park, State College, PA 16802, USA. ${ }^{6}$ Department of Biology, The Pennsylvania State University, 208 Curtin Rd, University Park, PA 16802, USA. 7 The Huck Institutes of the Life Sciences, The Pennsylvania State University, 101 Huck Life Sciences Building, University Park, PA 16802, USA.
\end{abstract}

Published online: 28 July 2020

\section{Reference}

1. Loeffler $\mathrm{C}$, et al. Improving the usability and comprehensiveness of microbial databases. BMC Biol. 2020;18:37 https://doi.org/10.1186/s12915020-0756-z.

\footnotetext{
The original article can be found online at https://doi.org/10.1186/s12915020-0756-z.

*Correspondence: cloeffler@ucla.edu; serghei.mangul@gmail.com

${ }^{\dagger}$ Caitlin Loeffler and Aaron Karlsberg contributed equally to this work.

'Department of Computer Science, University of California Los Angeles, 404 Westwood Plaza, Los Angeles, CA 90095, USA

${ }^{2}$ Department of Clinical Pharmacy, University of Southern California School of Pharmacy, 1985 Zonal Ave, Los Angeles, CA 90089, USA

Full list of author information is available at the end of the article
}

(C) The Author(s). 2020 Open Access This article is licensed under a Creative Commons Attribution 4.0 International License, which permits use, sharing, adaptation, distribution and reproduction in any medium or format, as long as you give appropriate credit to the original author(s) and the source, provide a link to the Creative Commons licence, and indicate if changes were made. The images or other third party material in this article are included in the article's Creative Commons licence, unless indicated otherwise in a credit line to the material. If material is not included in the article's Creative Commons licence and your intended use is not permitted by statutory regulation or exceeds the permitted use, you will need to obtain permission directly from the copyright holder. To view a copy of this licence, visit http://creativecommons.org/licenses/by/4.0/ The Creative Commons Public Domain Dedication waiver (http://creativecommons.org/publicdomain/zero/1.0/) applies to the data made available in this article, unless otherwise stated in a credit line to the data. 